\title{
Improvements of City Logistics Methods in Thriasio Area, Greece
}

\author{
Sotiria Michael, Michail Papoutsidakis, George Priniotakis \\ Department of Industrial Design and Production Engineering, University of West Attica, Athens, Greece \\ Email: mipapou@uniwa.gr
}

How to cite this paper: Michael, S., Papoutsidakis, M. and Priniotakis, G. (2020) Improvements of City Logistics Methods in Thriasio Area, Greece. Open Journal of Applied Sciences, 10, 767-778.

https://doi.org/10.4236/ojapps.2020.1012054

Received: September 20, 2020

Accepted: December 8, 2020

Published: December 11, 2020

Copyright (c) 2020 by author(s) and Scientific Research Publishing Inc. This work is licensed under the Creative Commons Attribution International License (CC BY 4.0).

http://creativecommons.org/licenses/by/4.0/

\section{(c) (i) Open Access}

\begin{abstract}
Urban freight transport is a very important part of the logistics chain. Creating the right conditions for the economic and commercial development of urban transport is extremely important. The purpose of this paper is to explore the concept of city logistics while presenting the situation in Greece, a country lagging in the implementation of good practices, and some suggestions for improving the existing reality of urban transport. In order to achieve the objectives of the present work, a review of the relevant literature and primary research, was conducted through personal interviews for the implementation of urban freight transport. The results, according to the literature, have shown that designing the right way and organizing an appropriate route for the product increases the quantities produced that are shipped for sale, either directly from the producers, through traders, suppliers, or logistics companies, which simply carry the products. Wrong design, on the other hand, leads to a complex system with significant losses, both in cost and quality. Also, according to primary research, businesses now active in the Thriasio area report the importance and positive impact they have had on the wider local community, as well as that urban shopping centers play a very important role, organizing and coordinating freight transport in the city centers. Moreover, the establishment of businesses in the center of Thriasio gives a positive impact on their establishment as their business has evolved and increased.
\end{abstract}

\section{Keywords}

Supply Chain, Logistics, City Logistics, Urban Transport, Urban Freight Centers, Thriasio Area

\section{Introduction}

The word "logistics" is derived from the Greek adjective "logistikos" meaning 
"skilled in calculating". The first administrative use of the word was in Roman and Byzantine times when there was a military administrative official with the title Logista. At that time, the word implied a skill involved in numerical computations. History shows the Benefit and Importance of Logistics [1].

Urban freight transport is a very important part of the logistics chain. The majority of completed transfers, regardless of the medium used and the distance traveled, end up as distribution within the city [2].

The problems that carriers face in big cities are many, with the lack of space for safe landing, traffic, and incomplete information on the best and most efficient routes being the major ones. Moreover, because of the constant transit of trucks in the urban area, cities suffer from air pollution, noise, and traffic congestion [3].

Carriers are constantly striving to provide better and better transport services at the least possible cost. One way to achieve this is to always calculate the optimal routes within a system in order to reduce unnecessary traffic that would burden the city's road network, which would cost unnecessary expands to the businesses themselves. This is the key component that City Logistics deals with in combination with other applications and the development of urban freight centers [4].

In particular, logistics is a complex concept as it covers many processes related to transport planning, implementation, and control. They are part of the supply chain, which designs, controls, and implements the flow and storage of goods, services, and related information, from point of origin to point of consumption, in a way that is consistent with customer needs. One definition given to the term logistics is that it is "the process of designing, implementing and controlling the efficient and economic flow and storage of raw materials, semi-finished and finished products, and related information, for the purpose of moving from point of production to point of view, to achieve customer satisfaction" [5].

Moreover, cities are facing global investment and trade competition with a transport system ideal for economic prosperity. Thus, logistics systems that are efficient and environmentally friendly can help cities become more competitive and grow economically [6].

This part comes to cover city logistics, which differ from general logistics due to their unique features and limitations. Specifically, city logistics can be separated into storage, transportation, and management, and differ from general logistics, as they emphasize the distribution and transportation of goods by suppliers/distributors in central cities [7].

According to Taniguchi et al. (2002), city logistics is defined as "the process of improving the logistics and transport processes of private companies in urban areas, taking into account the environment, congestion and energy consumption, through a market economy framework". In addition, Barcelo and Hanna (2005) define city logistics as "the transportation of cargoes to urban areas and in particular cargo flows related to supplying urban centers with 
goods" [8] [9].

The urban transport context is made up of local society, transport infrastructure, the legal environment, and the urban environment. Whereas, those involved in the city logistics system are mainly producers, traders, companies providing logistics services, carriers, warehousing companies, and end consumers (Figure 1).

The most important points related to urban freight transport that serve the existence of city logistics are the following [10]:

- Their total cost, as it relates to the efficiency of the economy, that is, the lower the cost of transport, the greater the efficiency of the economy;

- Meeting environmental, social, and economic needs;

- The creation of new jobs and their general importance to economic activity;

- Their contribution to the competitiveness of industrial and commercial activities;

- Ensure the supply of products to the marketplace at the right time.

\section{Transport Models}

\subsection{European Transport Models}

Most city logistics models have been developed in Europe, possibly because the countries of the European continent are interconnected and costs have increased because several borders have to be crossed [12].

\subsubsection{Transportation Model SAMGODS}

The model SAMGODS developed by the Swedish Institute of Transport in 2001. The model refers to the assembly and individualization of products during distribution and was originally developed for transport between Norway and Sweden. The model is based on the logic of establishing product distribution centers for efficient management. This model can also be applied to City Logistics [13].

Regional economy

Legal conditions

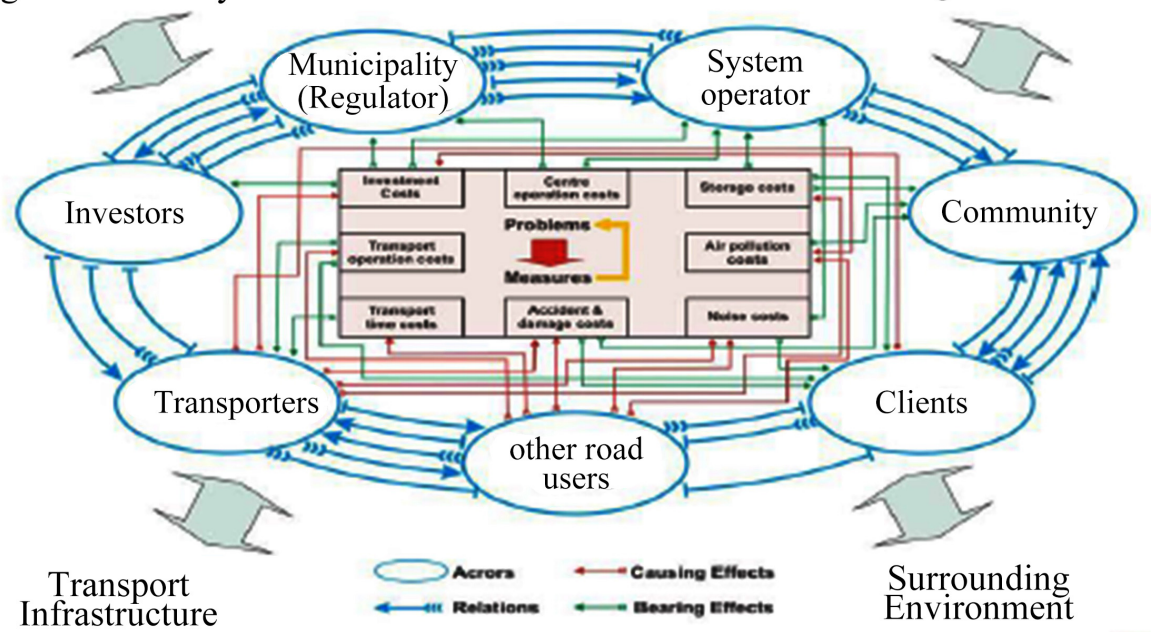

Figure 1. The system and stakeholders of city logistics [11]. 


\subsubsection{Transportation Model SMILE}

The model SMILE was developed in the Netherlands and derives its name from the original Strategic Model for Integrated Logistics and Evaluations. It was the first model to evaluate the routes of trucks carrying products and is considered the forerunner of the models developed through GIS to find the optimal route. This one can be both applied to national and urban level [14] [15].

\subsubsection{Transportation Model G00DTRIP}

GOODTRIP is a model that is very close to SMILE, and can determine transport costs and efficiency. However, this model applies to specific transportation products as noted such as food, books, and retailing. It can be applied and applied to City Logistics because of the nature of the products it can manage [16].

\subsubsection{Transportation Model EUNET 2.0}

This model was created in 2003 in the UK and examines the flow of products from the merchant to the customer's door, breaking down the process of transport to individual segments. The model was based on Tables of Origin and Destination and took into account different urban freight centers rather than concentrating goods in one, out of town [17].

In Europe, the Netherlands and Germany are regarded as the model countries in the development of combined transport and logistics centers, which are regarded as the main gateways to the EU's transit trade for Asia and America. In the Netherlands, the major ports (Rotterdam, Antwerp) have been transformed into modern intermodal networks, as they are adjacent to the rail and road network, and modern logistics parks have been erected near them [18].

A similar model has been created in Germany, with the only difference being that cabotage (inland transport) is given a greater dimension. In Germany, which has decentralized infrastructure, particular emphasis is placed on the development of the rail network: a dedicated body called GVZ has been set up exclusively for the co-operation and negotiation between the public organizations with the Logistics community of the country. In Mediterranean countries, such as Italy and Spain, freight centers are not only used as warehouses to cover combined transport, but also for wholesalers, as well as for the operation of offices and entertainment venues [19].

\section{The Principle and Distribution of Logistics in Greece}

In Greece, supply chain management has been slow to implement in its integrated sense. The effort was launched, as in other countries, by the Armed Forces, since in them the concept of supporting weapons systems is a compulsory one and the cost element has not played an important role until recently.

The point of reference for the development of logistics in the Greek market was the 2004 Olympic Games. Since then, the value of the Greek market has been maintained at a high level with the results of activating businesses for the development of logistics. Besides, the Greek ports were redeveloped and con- 
verted into commercial centers, making logistics development inevitable [20] [21].

Now, according to Georgiadis (2008), the supply chain situation in Greece is as follows:

- Large corporations have realized the need for supply chain management and are seeking to implement organizational change and create integrated supply chain management processes.

- The wider public sector fails to understand the concept and functions of supply chain management and thus makes public organizations ineffective.

- In small and medium-sized enterprises, the picture is frustrating

In conclusion, it is worth noting that the future and continued development and evolution of logistics in Greece will depend initially on the training and development of programs that will fill the gap in the way the supply chain operates and operates. Also, it will be based on the existence of visionary entrepreneurs who can grasp the advantages of the supply chain and its integrated applications. In addition, the development of supply chain and infrastructure management systems that will facilitate transportation is natural to bring about an increase in logistics, and thus an increase in the operation of businesses [22].

\section{Urban Freight Centers}

Urban freight centers can bring together the whole supply chain services in one place. This creates the conditions for synergies between the companies involved in the logistics industry [23].

The creation of urban freight centers in areas outside of the city, but close to them, also enables quick access without problems in the operation of the city [24].

Urban distribution centers play a major role in organizing and coordinating freight transport in city centers. They are the points of concentration of goods in the supply chain.

Product resellers have created large store chains, with the result that these companies have created urban merchandise centers for the collection, as well as the separation and storage of goods supplied by supplier companies (producers, freight forwarders). Distribute them at points of sale, basically within urban centers, according to their daily needs [25].

In this way, the problems of freight transport are eliminated when the operations of the supply chain are integrated into the operations of businesses.

Urban freight centers have several advantages. A distinctive advantage is the focus on specific retail activities resulting in growth in other areas of economic activity. Many people in the logistics industry are unaware of the benefits of urban shopping malls and often find that they increase costs and reduce supply chain control [2].

The development of urban freight centers has had positive effects on reducing traffic on city streets, reducing air pollutants in the city center, reducing overall 
energy consumption, and reducing the cost of product distribution. A typical example is the Netherlands, Germany, and England, which apply all the practices of city logistics and are the main gateways for the export of goods from $\mathrm{Eu}$ rope to Asia and the Americas [26].

\section{Thriasio Area Freight Center}

The creation of the first freight center in Greece, in the Thriasio area, was founded by Freight Centers SA, a subsidiary of OSE. The location of the Thriasio area, in Aspropyrgos Attica, is considered to be optimal for the development of logistics activities in Attica, as it is possible to connect the Shopping Center with the Attica Road, NATO Avenue, and the railway connection to the port of, Piraeus, Acharnes Railway Station and Eleftherios Venizelos Airport via Suburban Railway.

Thriasio center covers an area of approximately $1.500 .000 \mathrm{~m}$. and has a railway line from the port of Piraeus (Neo Ikonio area) to the freight station. The route is used solely by freight trains and through it, products imported into Greece via the port will be driven to their final destinations across the country by train or vice versa, thereby contributing to the development of combined freight [27].

It is targeted at Third-party logistics (3PL) companies, which form partnerships that will lead to increased combined transport, lower transport costs, and protect the environment.

The development of the Thriasio freight center has as its main purpose the concentration of all the scattered activities that currently exist in the area of the capital (sorting station, containers station, customs, commercial station, warehouses, etc.). The most significant investments were made to develop the first freight center in the greater Attica area, which will serve and cover all modes of transport (freight-train-ship) (Picture 1).

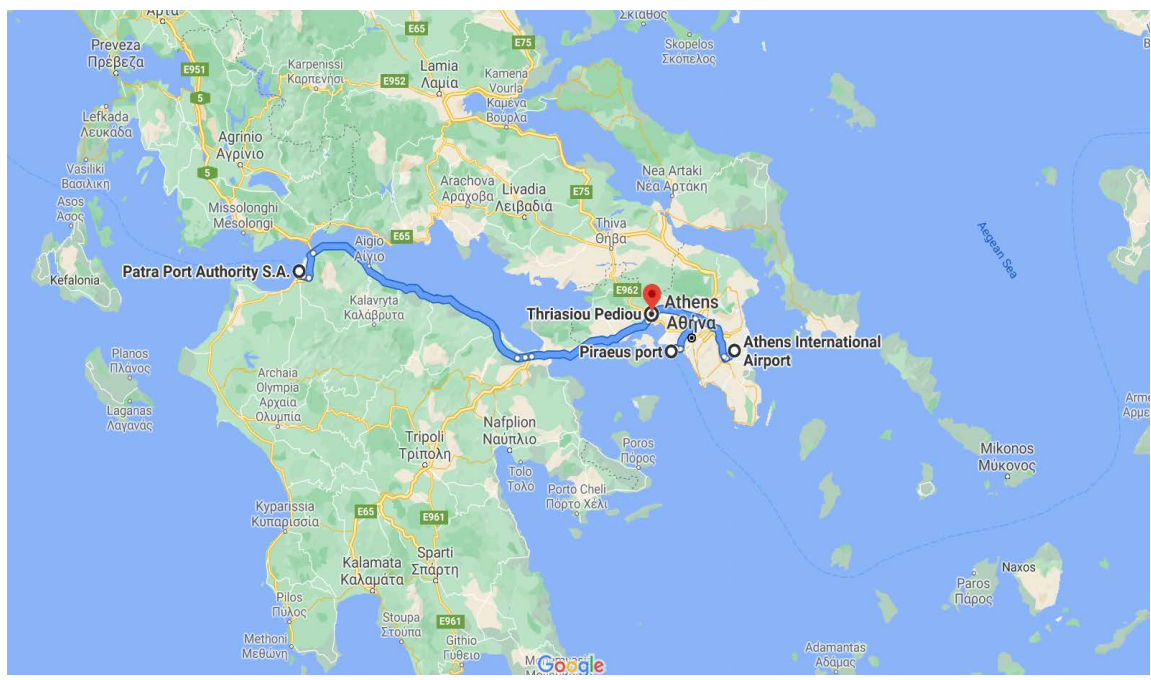

Picture 1. Google map attica area. 


\section{Methodology}

In order to achieve the objectives of this study, qualitative research was conducted. Qualitative research is a type of research that examines the topic that is studied in-depth and serves to study the views of the participants. Furthermore, in qualitative research, the researcher can observe, interpret, and analyze the views of the participants, according to their knowledge, and their critical point of view. Finally, qualitative research enables the researcher to understand the subject under study from a different perspective.

The research tool supported its creation in the preceding bibliographic review and in the study of similar studies. The contribution of business to the local community, the changes it has undergone, and its developments since its inception in Thriasio, are expected to be explored through questions in the form of structured interviews with selected business employees.

The sample of the research consists of eight employees in companies operating in the Thriasio area. The method used was that of the structured interview and the questions asked were intended to capture the views of the employees themselves.

The interviews included questions about the contribution of businesses to the local community, the changes that companies have made since their activation in the Thriasio area, and the enhancement of entrepreneurship after the companies were established and active in the Thriasio area. Interviews were conducted between August 1 and September 30, 2019, and the average duration per interview was 15 minutes.

\section{Results}

After the text edit has been completed, the paper is ready for the template. Duplicate the template file by using the Save As command, and use the naming convention prescribed by your journal for the name of your paper. In this newly created file, highlight all of the contents and import your prepared text file. You are now ready to style your paper.

\section{Contribution to Businesses}

Starting from the first thematic axis on the contribution of businesses to the wider local Thriasio community, it is observed that all the companies involved in the research have made a positive contribution to strengthening the local community. In particular, all the companies concerned have enriched their clientele with local partners for proximity reasons. Meanwhile, the proportion of its employees in the surrounding area has also increased. In more detail, Vioral SA reports that about half of its employees reside in the surrounding area, Fourarnakis SA reports that employees residing in the surrounding area reach $30 \%$, and DB Schenker SA, that this percentage is from $2 \%$ to $3 \%$.

In conclusion, it is observed that the research conducted is in line with the literature. This is because all the companies involved in the survey report that 
they have made a positive contribution to strengthening the local community, which is also emphasized by Theodoropoulou and Kassolis (2014), as they suggest that the development of urban freight centers can help develop jobs in developing areas [28].

\section{Changes in Business}

Continuing with the 2nd thematic axis and the changes that have been made or are prepared by businesses to make after their installation in the Thriasio area, it is observed that all businesses have noticed changes in the business. In particular, all the companies concerned have undergone technological changes and innovations since their installation in the Thriasio area and beyond, although none of these detailed the changes for competition reasons. However, by Fournarakis SA it is reported that one of the most important innovations the company has made is the installation of a robotic warehousing system in stock.

Also, all eight companies report that changes have been observed, such as: in sales, after their installation in Thriasio. In particular, as reported by DB Schenker SA The key competitive advantage of businesses is the direct access to our networks and the accessibility of each of our customers "or partners" carriers for deliveries or deliveries of their goods. Additionally, there is an increasing demand for storage services due to the immediate access of networks for deliveries within Attica - better timely service and transportation management. Also, Fournarakis SA agrees with the above point of view and states that the business is increasing its turnover, which is partly due to its geographical location, due to its direct access to the transport network [29].

This, as can be understood, has had a positive impact on businesses by offering them the opportunity to gain a competitive advantage and increase their profits vis-à-vis other businesses that refuse or are afraid to relocate to such a strategic location [30] [31].

From the analysis of the interviews, it is observed that the participating businesses agree with the results of the literature, as urban freight centers play a very important role in organizing and coordinating freight transport in the city centers. More specifically, the development of urban freight centers has helped reduce the number of routes, make more efficient use of vehicles and drivers and reduce transport costs. Also, the creation of urban freight centers in areas outside of the city, but close to them, enables quick access without creating problems in the operation of the city. Data also cited by the research firms, pointing out that the business is increasing its turnover, partly due to its geographical location, due to its direct access to the transport network [32] [33].

\section{Enhancing Entrepreneurship}

Besides, regarding the 3rd theme of this work, which is related to the enhancement of the research activity of the research participants after their establishment in the Thriasio area, it is observed that all the companies involved in the 
research give a positive performance to their establishment in Thriasio.

In particular, regarding the evolution of the business and the development of new partnerships and activities, all businesses emphasize that changes have taken place and that the evolution of the business is quite good. More specifically, DB Schenker SA reports that business development is good for the country, but to a large extent its business is based on Greece's general economy and international trends, with market trends for the next 3 to 4 years showing a significant growth rate of $2 \%-4 \%$. On the other hand, Fournarakis SA reports on the evolution of the company, stressing, however, those new business activities are few, as opposed to new partnerships both in the customer base and in the supplier partner segment. This is due to the concentration in the same geographical area of several companies that are leading their industry.

Finally, regarding the enhancement of the business activity of the companies involved in the survey, six out of eight report that it relates to government grants, funds, sponsorships, etc. that the company has a positive sign. In particular, Fournarakis SA reports that the company is increasing its turnover both in Greece and its imports - exports. On the other hand, Vioral SA cannot have any criterion as the company deals only with exports and is not affected by Greece, and DB Schenker SA, has not noticed any enhancement in its business since its establishment in the Thriasio area.

In conclusion, it can be observed that all the companies involved in the research give a positive view of their establishment in Thriasio, which is in agreement with the literature. Specifically, the majority of businesses surveyed report that their business has evolved and grown and is related to government grants, funds, sponsorships, etc. At the same time, the literature indicates that there is a variety of funding for business activities in urban freight centers.

\section{Proposals for Effective Urban Transport}

Nowadays, as observed by the literature and research conducted, urban transport is carried out without integrated systems and rules [34]. For this reason, it is necessary to put forward some proposals which contribute to the creation of integrated and efficient urban transport systems.

Thus, it is initially proposed that route optimization and proper management of the media fleet could achieve better results and savings in fuel and other resources (reduced mileage, operating costs, etc.) and in time [35].

Moreover, timetables and catering positions could be set which would disengage urban centers and make carriers' jobs easier, faster, and more efficient. In conjunction with this, it is proposed to define night distributions, which facilitate urban transport due to reduced traffic, and the possible use of fewer vehicles [36].

Another proposal could be the creation of dedicated truck lanes, which help reduce the latency and travel time of trucks carrying goods within the city. This measure follows the specifications of buses and enables trucks to move faster, 
thus more efficiently.

In conclusion, urban freight centers are an important factor in the successful implementation of urban freight transport. These centers can help make better and more efficient use of the corporate fleet and its human resources, as well as ensuring less hassle-free transport activities. Finally, with urban freight centers, it is easier to achieve better control over product stocks, product availability, scheduling and transport, and thus final customer service.

\section{Conclusions}

Urban freight transport is a very important part of the logistics chain. The majority of transfers completed, regardless of the medium used and the distance traveled, end up as distribution within the city. For this reason, these transport operations must function smoothly, offering those living, moving, and operating in these centers unrestricted access to goods and raw materials.

In Greece, urban transport has not been optimally developed. Although some measures, such as loading and unloading positions or setting timetables, are implemented, this implementation is not organized and effective. One reason this situation is attributed to the financial crisis is that local authorities and the state are unable to invest in infrastructure in city logistics, and the decline in the profits of businesses operating in logistics has made them unable to implement effective practices and solutions.

In conclusion, it could be argued that nowadays, while economies are growing and consumerism-demand for products-is increasing, urban transport, in particular, should be able to meet the needs and requirements of customers, ensuring environmental protection and to provide faster, more economical and safer transportation of products [37].

In conclusion, the most effective measures for sustainable Urban Freight Transport are those that simultaneously meet economic, environmental, and social needs, limiting the compromises between the objectives and the corresponding costs [38].

\section{Acknowledgements}

All authors would like to thank the University of West Attica and specifically the Post Graduate Program of Studies (MSc) "New Technologies in Shipping and Transport", for the financial support provided to them to undertake this research project.

\section{Conflicts of Interest}

The authors declare no conflicts of interest regarding the publication of this paper.

\section{References}

[1] The Chartered Institute of Building (2018) New Code of Estimating Practice. John 
Wiley \& Sons Ltd., Hoboken.

[2] Biniaris, S. (2014) Introduction to Supply Chain Management. PH Pasalides Publications, Athens.

[3] Malindretos, G. and Abeliotis, K. (2009) Sustainable City Logistics Practices for Goods and Waste. Harokopion University, Athens.

[4] Liu, X.M. and Savy, M. (2012) Logistics and the City: The Key Issue of Freight Villages. In: Mackett, R.L., May, A.D., Kii, M. and Pan, H., Eds., Sustainable Transport for Chinese Cities (Transport and Sustainability, Vol. 3), Emerald Group Publishing Limited, Bingley, 297-318.

[5] Malindretos, G. (2010) Special Issues in Supply Chain. Course Notes, Harokopio University, Athens.

[6] Dablanc, L. and Rodriguez, J.P. (2014) City Logistics: Towards a Global Typology. Transport Research Arena, Paris.

[7] Herwig, W. and Gottfried, S. (2011) Management of Freight Villages: Findings from an Exploratory Study in Germany. International Journal of Logistics, 14, 271-283.

[8] Foltyński, M. (2019) Sustainable Urban Logistics Plan-Current Situation of the City of Poznań. Transportation Research Procedia, 39, 42-53. https://doi.org/10.1016/j.trpro.2019.06.006

[9] Gorcun, F. (2014) Efficiency Analysis of Cargo Tram for City Logistics Compared to Road Freight Transportation: A Case Study Analysis of Istanbul City. Business Logistics in Modern Management, 14, 131-140.

[10] Taniguchi, E., Thompson, R. and Yamada, T. (2003) Visions for City Logistics. In: Taniguchi, E. and Thompson, R.G., Eds., Logistics Systems for Sustainable Cities, Emerald Group Publishing Limited, 1-16.

https://doi.org/10.1108/9780080473222-001

[11] Kiba-Janiak, M. (2016) Key Success Factors for City Logistics from the Perspective of Various Groups of Stakeholders. Transportation Research Procedia, 12, 557-569. https://doi.org/10.1016/j.trpro.2016.02.011

[12] Neuhold, G. (2005) The Environmental Savings of Using Other Modes. BESTUFS.

[13] Kiba-Janiak, M. and Cheba, K. (2019) Information System for City Logistics. The Case of Poland. Transportation Research Procedia, 39, 160-169. https://doi.org/10.1016/j.trpro.2019.06.018

[14] Bestufs (Best Urban Freight Solutions) Consortium (2007) Best Practices Guide for Urban Freight Transport. Research Program in Research and Technologies (RTD).

[15] Tsipouras, Ch. (2010) Transportation, Storage, Supply Chain Management Systems as a Competitive Advantage for the Modern Company \& Its Evaluation Methods. Piraeus University Postgraduate Program, Piraeus.

[16] Boerkamps, J. and van Binsbergen, A. (1999) GOOTRIP-A New Approach for Modeling and Evaluation of Urban Goods Distribution Urban Transport Systems. The 2nd KFB-Research Conference, Lund.

[17] Mitra, S., Lee, E., DeHaan, C., Kayabas, P. and Itani, M. (2013) Integrating Supply Chain Models in Urban Freight Planning. Upper Great Plains Transportation Institute, North Dakota State University, Fargo.

[18] Benjelloun, A., Crainic, T.G. and Bigras, Y. (2009) Toward a Taxonomy of City Logistics Projects. Interuniversity Research Centre on Enterprise Networks, Logistics and Transportation.

[19] Reguea, R. and Bristow, A. (2013) Appraising Freight Tram Schemes: A Case Study 
of Barcelona. Institute of Transportation Studies, University of California, Oakland.

[20] Laios, L. and Pastroumas, A. (1999) The Logistics Penetration in Greek Businesses. Important Research Notes of Piraeus University, Piraeus.

[21] Porter, M. and Kramer, M.R. (2011) Creating Shared Value. Harvard Business Review, January-February Issue.

[22] Ramokgopa, L.N. (2004) City Logistics: Changing the Way We Supply. Proceedings of the 23 rd Southern African Transport Conference.

[23] Kulińska, E. and Kulińska, K. (2019) Development of Ride-Sourcing Services and Sustainable City Logistics. Transportation Research Procedia, 39, 252-259. https://doi.org/10.1016/j.trpro.2019.06.027

[24] Kauf, S. (2016) City Logistics-A Strategic Element of Sustainable Urban Development. Transportation Research Procedia, 16, 158-164.

https://doi.org/10.1016/j.trpro.2016.11.016

[25] European Parliament (2008) Freight Transport Logistics in Europe, Report on Freight Transport in Europe, Committee on Transport and Tourism, Rapporteur: Michael Cramer.

[26] Dalia, A. (2012) Feasibility Study of Freight Center Implementation. NTUA, Athens.

[27] Desiderio, M. (2008) DHL Amsterdam, Combined Transport: Boat \& Bike. Transport Expertise Association. English Publications.

[28] Theodoropoulou, R. and Kassoli, M. (2014) Transport \& Logistics. General Secretariat for Research and Technology, Athens.

[29] Dablanc, L. (2019) City Logistics. In: International Encyclopedia of Geography: People, the Earth, Environment and Technology, Wiley Online Library. https://doi.org/10.1002/9781118786352.wbieg0137.pub2

[30] Malindretos, G. (2009) Logistics Strategy and Sustainability. In: The 2nd EuroMed Conference of the EuroMed Academy of Business, University of Salerno, Salerno.

[31] Savelsbergh, M. and Van Woensel, T. (2016) 50th Anniversary Invited Article-City Logistics: Challenges and Opportunities. Transportation Science, 50, 363-761. https://doi.org/10.1287/trsc.2016.0675

[32] Metaxakis, I. (2010) Urban Logistics-CityLogistics. University of the Aegean, Chios.

[33] Daganzo, F. (2007) Logistics Systems Analysis. Berlin.

[34] Malindretos, G. (2016) Supply Chain-Logistics and Customer Service. Academic Library Association, Athens.

[35] Papadopoulos, A. (2015) The Problem of Vehicle Routing: A Case Study. University of Patras, Patras.

[36] Papayannnoulis, I. (2011) Intelligent Transport Systems. University of Piraeus, Piraeus.

[37] Tadić, S., Zečević, S. and Krstić, M. (2018) Assessment of the Political City Logistics Initiatives Sustainability. Transportation Research Procedia, 30, 285-294. https://doi.org/10.1016/j.trpro.2018.09.031

[38] Nathanail, E., Adamos, G. and Gogas, M. (2017) A Novel Approach for Assessing Sustainable City Logistics. Transportation Research Procedia, 25, 1036-1045.

https://doi.org/10.1016/j.trpro.2017.05.477 